\title{
Statistical Forecast of Pollution Episodes in Macao during National Holiday and COVID-19
}

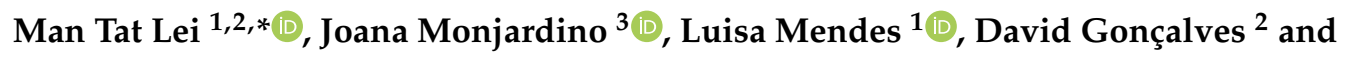 \\ Francisco Ferreira ${ }^{3}$ (D) \\ 1 Department of Sciences and Environmental Engineering, NOVA School of Science and Technology, \\ NOVA University Lisbon, 2829-516 Caparica, Portugal; lc.mendes@fct.unl.pt \\ 2 Institute of Science and Environment, University of Saint Joseph, Macau 999078, China; \\ david.goncalves@usj.edu.mo \\ 3 Center for Environmental and Sustainability Research, NOVA School of Science and Technology, \\ NOVA University Lisbon, 2829-516 Caparica, Portugal; jvm@fct.unl.pt (J.M.); ff@fct.unl.pt (F.F.) \\ * Correspondence: 1.tat@campus.fct.unl.pt or lei.man.tat@usj.edu.mo
}

Received: 27 May 2020; Accepted: 14 July 2020; Published: 15 July 2020

\begin{abstract}
Statistical methods such as multiple linear regression (MLR) and classification and regression tree (CART) analysis were used to build prediction models for the levels of pollutant concentrations in Macao using meteorological and air quality historical data to three periods: (i) from 2013 to 2016, (ii) from 2015 to 2018, and (iii) from 2013 to 2018. The variables retained by the models were identical for nitrogen dioxide $\left(\mathrm{NO}_{2}\right)$, particulate matter $\left(\mathrm{PM}_{10}\right), \mathrm{PM}_{2.5}$, but not for ozone $\left(\mathrm{O}_{3}\right)$ Air pollution data from 2019 was used for validation purposes. The model for the 2013 to 2018 period was the one that performed best in prediction of the next-day concentrations levels in 2019, with high coefficient of determination $\left(\mathrm{R}^{2}\right)$, between predicted and observed daily average concentrations (between 0.78 and 0.89 for all pollutants), and low root mean square error (RMSE), mean absolute error (MAE), and biases (BIAS). To understand if the prediction model was robust to extreme variations in pollutants concentration, a test was performed under the circumstances of a high pollution episode for $\mathrm{PM}_{2.5}$ and $\mathrm{O}_{3}$ during 2019, and the low pollution episode during the period of implementation of the preventive measures for COVID-19 pandemic. Regarding the high pollution episode, the period of the Chinese National Holiday of 2019 was selected, in which high concentration levels were identified for $\mathrm{PM}_{2.5}$ and $\mathrm{O}_{3}$, with peaks of daily concentration exceeding $55 \mu \mathrm{g} / \mathrm{m}^{3}$ and $400 \mu \mathrm{g} / \mathrm{m}^{3}$, respectively. The 2013 to 2018 model successfully predicted this high pollution episode with high coefficients of determination (of 0.92 for $\mathrm{PM}_{2.5}$ and 0.82 for $\mathrm{O}_{3}$ ). The low pollution episode for $\mathrm{PM}_{2.5}$ and $\mathrm{O}_{3}$ was identified during the 2020 COVID-19 pandemic period, with a low record of daily concentration for $\mathrm{PM}_{2.5}$ levels at $2 \mu \mathrm{g} / \mathrm{m}^{3}$ and $\mathrm{O}_{3}$ levels at $50 \mu \mathrm{g} / \mathrm{m}^{3}$, respectively. The 2013 to 2018 model successfully predicted the low pollution episode for $\mathrm{PM}_{2.5}$ and $\mathrm{O}_{3}$ with a high coefficient of determination (0.86 and 0.84 , respectively). Overall, the results demonstrate that the statistical forecast model is robust and able to correctly reproduce extreme air pollution events of both high and low concentration levels.
\end{abstract}

Keywords: air pollution; air quality forecast; modelling; pollution episodes; national holiday; COVID-19

\section{Introduction}

The development of air quality forecast models is essential for cities with high population density, including Macao, one of the most densely populated cities in the world. It is extremely important to predict pollution episodes so the authority can provide a warning to the local community in advance to avoid the adverse air quality, which may lead to severe health consequences. In order to predict 
next-day concentrations of nitrogen dioxide $\left(\mathrm{NO}_{2}\right)$, particulate matter $\left(\mathrm{PM}_{10}\right.$ and $\left.\mathrm{PM}_{2.5}\right)$, and maximum hourly concentration of ozone $\left(\mathrm{O}_{3 \mathrm{MAX}}\right)$ for roadside, ambient, and residential stations in Macao, a forecast model was developed based on statistical methods using multiple linear regression (MLR) and classification and regression tree (CART) analysis.

There are three forms of total suspended particles (TSPs), which include coarse, fine, and ultrafine particles. Coarse particles, also known as $\mathrm{PM}_{10}$, are derived from suspension of dust, soil, sea salts, pollen, mold, and other crustal materials. Fine particles, also known as $\mathrm{PM}_{2.5}$, are derived from emissions from combustion process, including vehicles powered by petrol and diesel, wood burning, coal burning, and other industrial processes. Ultrafine particles are derived from combustion related sources such as vehicle exhausts and atmospheric photochemical reactions [1].

$\mathrm{O}_{3}$ is the most important index substance for photochemical smog, one of the major air pollutants [2]. The formation of ground-level $\mathrm{O}_{3}$ heavily depends on the concentration levels of volatile organic compounds (VOCs) and nitrogen oxides $\left(\mathrm{NO}_{\mathrm{x}}\right)$ and meteorological factors such as wind speed, insolation, and temperature. $\mathrm{PM}_{2.5}$ and $\mathrm{O}_{3}$ pollutants are known to cause the most damages to the human respiratory and cardiovascular system. A study for Terengganu State, Malaysia, showed that high levels of $\mathrm{O}_{3}$ occurring under dry and warm conditions during the southwest monsoon, were higher in industrial areas, and were positively correlated with the maximum daily temperature [3].

The emission of $\mathrm{NO}_{\mathrm{x}}$ is primarily emitted from transportation and combustion process, while the emission of VOCs is primarily emitted from road traffic and the use of products containing organic solvents $[4,5]$.

The emission of $\mathrm{NO}_{\mathrm{x}}$ and VOCs is responsible for the $\mathrm{O}_{3}$ formation, in particular rural areas being $\mathrm{NO}_{x}$-sensitive while urban areas being VOC-sensitive. Nevertheless, the greater $\mathrm{NO}_{x}$ emission reductions have contributed to a widespread shift in the $\mathrm{O}_{3}$ production regime from $\mathrm{NO}_{\mathrm{x}}$-saturated (high- $\mathrm{NO}_{\mathrm{x}}$ ) to $\mathrm{NO}_{\mathrm{x}}$-sensitive (low- $\mathrm{NO}_{\mathrm{x}}$ ) in some urban areas, while $\mathrm{O}_{3}$ production in rural areas is even more sensitive to $\mathrm{NO}_{x}$.

TSPs are primary contributors to premature death worldwide, with over four million premature deaths being recorded due to exposure to high levels of ambient $\mathrm{PM}_{2.5}$ [6-8]. $\mathrm{PM}_{2.5}$ can penetrate deep into the lungs when being inhaled, which leads to both acute and chronic health issues [1,6]. $\mathrm{NO}_{2}$ and TSPs are responsible for 412,000 and 71,000 premature death per year, respectively, in the European Union $[9,10]$. Moreover, previous studies show a strong correlation between short-term exposure to $\mathrm{NO}_{2}$ and both the number of hospital outpatients with eye and adnexa diseases (EADs) [11] and the number of hospital admission due to cardiovascular diseases (CVD) [12]. The Chinese National Ambient Air Quality Standard (NAAQS) has set the threshold of $\mathrm{PM}_{10}, \mathrm{PM}_{2.5}$, and $\mathrm{O}_{3 \mathrm{MAX}}$ concentration at $150 \mu \mathrm{g} / \mathrm{m}^{3}, 75 \mu \mathrm{g} / \mathrm{m}^{3}$, and $160 \mu \mathrm{g} / \mathrm{m}^{3}$, respectively, while the WHO Air Quality Guideline has set the same thresholds at $50 \mu \mathrm{g} / \mathrm{m}^{3}, 25 \mu \mathrm{g} / \mathrm{m}^{3}$, and $100 \mu \mathrm{g} / \mathrm{m}^{3}$, respectively. Compliance with the thresholds set by the WHO for $\mathrm{PM}_{2.5}$ could improve life expectancy in China by 0.14 years [13] and ambient air pollution has caused at least 3.7 million deaths, with more than $25 \%$ of deaths in Southeast Asia [14,15].

Air pollution forecasting models can provide important information for populations to adopt mitigation measures during high pollution days. To be useful, these models should be robust to deal with extreme variations in pollution levels, in particular during high-pollution peak days. Factors leading to extreme variation in pollution levels are diverse and include both human activities and meteorological factors.

In a study for Beijing, China, the reduction of traffic flow and vehicle emissions in downtown areas during the Chinese National Holiday, reduced air pollution, while, in contrast, fireworks during the Chinese New Year Holiday had the opposite effect [16]. When highway tolls were being waived for passenger vehicles during the Chinese National Holiday across the entire nation of China, air pollution increased by $20 \%$ and visibility decreased by $1 \mathrm{~km}$, causing economic losses due to negative health impacts estimated at RMB 0.95 billion [17]. Nevertheless, the Chinese National Holiday is known to be a golden week of tourism, in which the Chinese tourist flock to different tourist destinations around the world to celebrate the national holiday. Due to the vibrant casinos and entertainment industry 
and close proximity to mainland China, Macao is also one of the favorite destinations for Chinese tourists, so the influx of tourist during the period of Chinese National Holiday may lead to an increase of emissions in Macao.

Likewise, the recent COVID-19 crisis has had an extreme impact in air pollution levels. The Wuhan Health Commission has first reported cases of pneumonia linked to the Wuhan wet market in Hubei Province, China, back in December 2019 [18]. Preventive measures were implemented soon after that abruptly reduced industrial activities and transportation. Nevertheless, the levels of air pollutants, in particular of $\mathrm{PM}_{2.5}$, remained severe in northern China throughout the end of January 2020 due to adverse meteorological conditions that have overwhelmed the benefits of emission reduction in transportation and industrial sectors [19].

Previous work showed that there is an increase in the level of $\mathrm{O}_{3}$ concentrations and a decrease in the level of $\mathrm{NO}_{2}, \mathrm{PM}_{10}$, and $\mathrm{PM}_{2.5}$ concentration during the period of COVID-19 pandemic lockdown in several cities of China, due to the significant reduction of transportation and industrial activities $[4,5,20,21]$.

Several methodologies have been developed and applied to forecast air quality across the world, including deterministic, statistical, and machine learning methods [22-26]. Some studies showed that statistical models are more accurate and efficient compared to deterministic models, particularly in regions with complexed terrain [27-30] Moreover, prediction of $\mathrm{NO}_{2}, \mathrm{PM}_{10}, \mathrm{PM}_{2.5}$, and $\mathrm{O}_{3 \mathrm{MAX}}$ concentrations based on MLR and CART models have been successfully implemented in Macao, Bangkok, Changsha City, Beijing, Bilbao, and Pakistan [26,31-35].

In this context, it is relevant to develop a reliable methodology to forecast the concentration of air pollutants, which is presented and tested for a high pollution episode (associated with the Chinese National Holiday) and a low pollution episode (during COVID-19 preventive measures).

\section{Materials and Methods}

The air quality and meteorological variables that were considered to build all of the air quality statistical models were obtained from Macao Meteorological and Geophysical Bureau (SMG). The air quality data was gathered from the air quality monitoring network, namely for: Macao Roadside, Macao Residential, Taipa Ambient, Taipa Residential, and Coloane Ambient stations, which have a suitable historic dataset of surface air quality measurements for the levels of $\mathrm{NO}_{2}, \mathrm{PM}_{10}, \mathrm{PM}_{2.5}$, and $\mathrm{O}_{3}$ concentrations. These background stations (residential and ambient) can capture the regional contribution of $\mathrm{PM}_{10}$ and $\mathrm{PM}_{2.5}$. There is a higher population and traffic density in Macao Roadside and Macao Residential, which are located in the main peninsula, in comparison to Taipa Ambient, Taipa Residential, and Coloane Ambient stations, which are located on the outlying islands.

Meteorological data was obtained from surface observations at SMG's Taipa Grande Meteorological Station, hourly observations from automatic weather stations, such as temperature, relative humidity, precipitation, average wind speed, and dew point temperature, as well as upper-air observations (from Hong Kong King's Park location) such as geopotential heights, thickness, stability, temperature, relative humidity, and dew point temperature at various altitudes. In the present work, statistical models such as multiple linear regression (MLR), and classification and regression tree (CART), are developed, based on historical measurements of meteorological and air quality variables. Table 1 presents all the variables considered as predictors in the MLR and CART forecast models, as shown in previous work [22]. The air quality variables considered included the levels of $\mathrm{NO}_{2}, \mathrm{PM}_{10}, \mathrm{PM}_{2.5}$, and $\mathrm{O}_{3} \mathrm{MAX}$ concentration from 00:00 to 23:00 of the previous day, two days and three days ago, and from 16:00 of the previous day and 15:00 of today. The meteorological variables being considered included the upper-air observations from King's Park location, Hong Kong Observatory, surface observations and other variables from the monitoring network of Macao Meteorological and Geophysical Bureau (SMG). 
Table 1. Variables considered as predictors in the multiple linear regression (MLR) and classification and regression tree (CART) models in all of the air quality forecast models.

\begin{tabular}{|c|c|c|}
\hline Variable Type & Variable Name & Variable Description (Units)/ Observations \\
\hline \multirow{4}{*}{ Air quality variables } & $\mathrm{NO}_{2}, \mathrm{PM}_{10}, \mathrm{PM}_{2.5}$ & Average hourly concentration values $\left(\mu \mathrm{g} / \mathrm{m}^{3}\right)$ \\
\hline & $\mathrm{O}_{3 \mathrm{MAX}}$ & Maximum hourly concentration values $\left(\mu \mathrm{g} / \mathrm{m}^{3}\right)$ \\
\hline & 16D\#, 23D\# & $\begin{array}{l}\text { 23D\#: 24-h concentration averaging period between } 00 \mathrm{~h} \text { and } 23 \mathrm{~h} \\
\text { 16D\#: 24-h concentration averaging period between 16h of D1 and 15h of D0 } \\
\text { eg: PM10_16D1, O3_MAX_23D1. }\end{array}$ \\
\hline & D0, D1, D2, D3 & D0: Forecast Day; D1: Previous Day (Forecast Day-1); D2: Forecast Day-2; and D3: Forecast Day-3. \\
\hline \multirow{6}{*}{ Meteorological variables } & \multirow{6}{*}{ Upper-air obs. * } & $\begin{array}{l}\text { Geopotential Height at } 1000 \mathrm{hPa}, 850 \mathrm{hPa}, 700 \mathrm{hPa} \text {, and } 500 \mathrm{hPa} \\
(\mathrm{m}) / \text { Indicator of synoptic-scale weather pattern. }\end{array}$ \\
\hline & & $\begin{array}{l}\text { Air Temperature at } 925 \mathrm{hPa}, 850 \mathrm{hPa} \text {, and } 700 \mathrm{hPa}\left({ }^{\circ} \mathrm{C}\right) / \text { Measure of } \\
\text { strength and height of the subsidence inversion. }\end{array}$ \\
\hline & & Relative Humidity at $925 \mathrm{hPa}, 850 \mathrm{hPa}$, and $700 \mathrm{hPa}(\%)$. \\
\hline & & Dew Point Temperature at $925 \mathrm{hPa}, 850 \mathrm{hPa}$, and $700 \mathrm{hPa}\left({ }^{\circ} \mathrm{C}\right)$ \\
\hline & & $\begin{array}{c}\text { Thickness at } 850 \mathrm{hPa}, 700 \mathrm{hPa} \text {, and } 500 \mathrm{hPa}(\mathrm{m}) / \text { Related to the mean } \\
\text { temperature in the layer. }\end{array}$ \\
\hline & & $\begin{array}{c}\text { Stability at } 925 \mathrm{hPa}, 850 \mathrm{hPa} \text {, and } 700 \mathrm{hPa}\left({ }^{\circ} \mathrm{C}\right) / \text { Indicator of } \\
\text { atmospheric stability. }\end{array}$ \\
\hline \multirow{5}{*}{ Surface observations } & T_AIR_MX, T_AIR_MD, T_AIR_MN & Maximum, Average, and Minimum Air Temperature $\left({ }^{\circ} \mathrm{C}\right)$ \\
\hline & HRMX, HRMD, HRMN & Maximum, Average, and Minimum Relative Humidity (\%) \\
\hline & TD_MD & Average dew point temperature (ground level) $\left({ }^{\circ} \mathrm{C}\right.$ ) \\
\hline & RRTT & Precipitation $(\mathrm{mm}) /$ Associated with atmospheric washout \\
\hline & VMED & Average wind speed $(\mathrm{m} / \mathrm{s}) /$ Related to dispersion \\
\hline \multirow{2}{*}{ Other variables } & DD & Duration of the day: number of hours of sun per day (h) \\
\hline & FF & Week-day indicator (flag): weekday $=0$, weekend $=1$ \\
\hline
\end{tabular}

Meteorological variables: * Daily sounding at 12H (GMT+8) at King's Park Meteorological Station—Hong Kong Observatory. 
In this study, meteorological and air quality variables for 2013 to 2016, 2015 to 2018, and 2013 to 2018 were used to build three separate forecasting models. The 2013 to 2016 model was constructed for the initial evaluation for the application of the statistical model to forecast air quality in Macao, while the 2015 to 2018 models and the 2013 to 2018 models are a follow-up, to determine if any improvement could be made with two additional years of data. The comparison of extended data ranging from 5 to 6 years are considered to be adequate lengths to test if there is any significant difference between the time series. Simultaneously, it would not be ideal to trace back too far with the time series, because regional emissions are constantly changing, and therefore the level of pollutants concentration may also be changing. The dataset from 2019 was the most recent dataset, which would be used for the model validation for all the models. This study is an empirical approach and also region-specific, which may also be chemical-regime dependent.

The final selected variables to predict the levels of $\mathrm{PM}_{2.5}$ and $\mathrm{O}_{3}$ concentration are common to different locations of Macao air quality monitoring stations. Some variables initially selected were rejected from the forecast models due to collinearity. The final objective is to obtain prediction models with the lowest number of variables, but with the maximum explained variance as translated by the coefficient of determination $\left(\mathrm{R}^{2}\right)$.

After selecting the best model, it was applied to forecast pollution levels during an extremely high pollution episode, and a low pollution period. The high and low pollution selected episodes were, respectively: (i) the period of Chinese National Holiday, a week before the Chinese National Holiday from September 23rd to 30th, 2019, and the week during the Chinese National Holiday from October 1st to 7th, and (ii) the preventive measures period of COVID-19, from February 5th to 20th, 2020.

The statistical model was built using IBM SPSS Statistics version 26 with MLR (stepwise) and CART methods [26,36]. SPSS is a statistical software that is applied to solve research problems through hypothesis testing and predictive analysis.

Model performance indicators were calculated, such as, coefficient of determination $\left(R^{2}\right)$, root mean square error (RMSE), mean absolute error (MAE), and systematic error (BIAS).

\section{Results and Discussion}

\subsection{Air Quality Forecast Models}

The model performance indicators obtained for the 2013 to 2016 model and for the 2013 to 2018 model, validated with 2019 data, are listed in Tables 2 and 3, respectively. The models chosen to figure in Tables 2 and 3 are the ones that performed the worst and best 2019 validation results.

The results showed that the model for the 2013 to 2018 period was the one that performed best in predicting next-day concentrations levels in 2019, with high $R^{2}$ between predicted and observed daily average concentrations (between 0.78 and 0.89 for all pollutants) and low RMSE, MAE, and BIAS. The additional two years of data helped to improve the air quality forecasting model. Nevertheless, with the two other models (2013-2016 and 2015-2018) a significant $R^{2}$ (between 0.78 and 0.89 for all pollutants) was also obtained, but it translated into a less reliable air quality forecast.

Regarding model performance indicators obtained per pollutant and station, the majority of models show a good agreement and a similar $R^{2}$ range values (from 0.81 to 0.89 ), except for $\mathrm{O}_{3} \mathrm{MAX}$, which is more difficult to predict. MLR was used for all pollutants, while CART analysis was used in almost all the $\mathrm{O}_{3 \mathrm{MAX}}$ models (Tables 2 and 3). This CART analysis complement was an approach to obtain improved results, mainly regarding a better prediction of high pollutant levels.

Table 4 presents the final model equations obtained for each pollutant, per air quality monitoring station, in the 2013 to 2018 model. Additionally, the final equations used to predict the levels of $\mathrm{NO}_{2}$, $\mathrm{PM}_{10}, \mathrm{PM}_{2.5}$, and $\mathrm{O}_{3 \_\mathrm{MAX}}$ concentrations are presented in Table 4. 
Table 2. Model performance indicators for the 2013 to 2016 model validation with 2019 data.

\begin{tabular}{|c|c|c|c|c|c|c|c|}
\hline \multirow[t]{2}{*}{ Station } & \multirow[t]{2}{*}{ Pollutant } & \multicolumn{4}{|c|}{ Model Performance Indicator } & \multicolumn{2}{|c|}{$\begin{array}{l}\text { Model Built Using Only } \\
\text { MLR or CART and MLR }\end{array}$} \\
\hline & & $\mathbf{R}^{2}$ & RMSE & MAE & BIAS & MLR & CART \\
\hline \multirow{3}{*}{ Macao Roadside } & $\mathrm{PM}_{10}$ & 0.88 & 8.6 & 5.8 & 1.8 & $\checkmark$ & \\
\hline & $\mathrm{PM}_{2.5}$ & 0.86 & 5.4 & 3.7 & 1.5 & $\checkmark$ & \\
\hline & $\mathrm{NO}_{2}$ & 0.89 & 8.0 & 5.9 & 0.4 & $\checkmark$ & \\
\hline \multirow{4}{*}{ Macao Residential } & $\mathrm{PM}_{10}$ & 0.89 & 8.8 & 5.9 & -0.3 & $\checkmark$ & \\
\hline & $\mathrm{PM}_{2.5}$ & 0.87 & 5.2 & 3.3 & 0.7 & $\checkmark$ & \\
\hline & $\mathrm{NO}_{2}$ & 0.86 & 7.7 & 5.5 & -0.4 & $\checkmark$ & \\
\hline & $\mathrm{O}_{3 \operatorname{MAX}}$ & 0.85 & 23.2 & 14.0 & 0.0 & $\checkmark$ & \\
\hline \multirow{4}{*}{ Taipa Ambient } & $\mathrm{PM}_{10}$ & 0.88 & 7.9 & 5.4 & 1.7 & $\checkmark$ & \\
\hline & $\mathrm{PM}_{2.5}$ & 0.86 & 5.1 & 3.6 & 1.6 & $\checkmark$ & \\
\hline & $\mathrm{NO}_{2}$ & 0.87 & 6.1 & 4.2 & 0.9 & $\checkmark$ & \\
\hline & $\mathrm{O}_{3 \mathrm{MAX}}$ & 0.86 & 24.4 & 14.8 & -2.1 & $\checkmark$ & $\checkmark$ \\
\hline \multirow{4}{*}{ Taipa Residential } & $\mathrm{PM}_{10}$ & 0.87 & 8.0 & 5.2 & 0.1 & $\checkmark$ & \\
\hline & $\mathrm{PM}_{2.5}$ & 0.88 & 5.7 & 3.5 & -0.1 & $\checkmark$ & \\
\hline & $\mathrm{NO}_{2}$ & 0.87 & 5.6 & 4.2 & 0.8 & $\checkmark$ & \\
\hline & $\mathrm{O}_{3 \mathrm{MAX}}$ & 0.78 & 20.9 & 12.7 & 1.3 & $\checkmark$ & $\checkmark$ \\
\hline \multirow{4}{*}{ Coloane Ambient } & $\mathrm{PM}_{10}$ & 0.88 & 8.7 & 6.2 & 2.4 & $\checkmark$ & \\
\hline & $\mathrm{PM}_{25}$ & 0.86 & 5.4 & 3.7 & 1.3 & $\checkmark$ & \\
\hline & $\mathrm{NO}_{2}$ & 0.81 & 7.8 & 5.5 & -0.2 & $\checkmark$ & \\
\hline & $\mathrm{O}_{3 \mathrm{MAX}}$ & 0.79 & 24.7 & 15.9 & -3.6 & $\checkmark$ & $\checkmark$ \\
\hline
\end{tabular}

Table 3. Model performance indicators for the 2013 to 2018 model validation with 2019 data.

\begin{tabular}{|c|c|c|c|c|c|c|c|}
\hline \multirow[t]{2}{*}{ Station } & \multirow[t]{2}{*}{ Pollutant } & \multicolumn{4}{|c|}{ Model Performance Indicator } & \multicolumn{2}{|c|}{$\begin{array}{l}\text { Model Built Using Only } \\
\text { MLR or CART and MLR }\end{array}$} \\
\hline & & $\mathbf{R}^{2}$ & RMSE & MAE & BIAS & MLR & CART \\
\hline \multirow{3}{*}{ Macao Roadside } & $\mathrm{PM}_{10}$ & 0.88 & 8.4 & 5.6 & 1.5 & $\checkmark$ & \\
\hline & $\mathrm{PM}_{2.5}$ & 0.87 & 5.2 & 3.3 & 0.2 & $\checkmark$ & \\
\hline & $\mathrm{NO}_{2}$ & 0.89 & 7.9 & 5.8 & -0.1 & $\checkmark$ & \\
\hline \multirow{4}{*}{ Macao Residential } & $\mathrm{PM}_{10}$ & 0.89 & 8.8 & 5.9 & -0.1 & $\checkmark$ & \\
\hline & $\mathrm{PM}_{2.5}$ & 0.87 & 5.2 & 3.3 & 0.8 & $\checkmark$ & \\
\hline & $\mathrm{NO}_{2}$ & 0.86 & 7.7 & 5.5 & 0.0 & $\checkmark$ & \\
\hline & $\mathrm{O}_{3 \operatorname{MAX}}$ & 0.85 & 23.2 & 14.0 & 0.0 & $\checkmark$ & \\
\hline \multirow{4}{*}{ Taipa Ambient } & $\mathrm{PM}_{10}$ & 0.88 & 7.8 & 5.1 & 0.8 & $\checkmark$ & \\
\hline & $\mathrm{PM}_{2.5}$ & 0.86 & 4.8 & 3.1 & 0.2 & $\checkmark$ & \\
\hline & $\mathrm{NO}_{2}$ & 0.87 & 6.1 & 4.2 & 1.0 & $\checkmark$ & \\
\hline & $\mathrm{O}_{3 \operatorname{MAX}}$ & 0.86 & 23.7 & 14.7 & -1.6 & $\checkmark$ & $\checkmark$ \\
\hline \multirow{4}{*}{ Taipa Residential } & $\mathrm{PM}_{10}$ & 0.88 & 7.9 & 5.1 & 0.2 & $\checkmark$ & \\
\hline & $\mathrm{PM}_{2.5}$ & 0.88 & 5.6 & 3.5 & -0.1 & $\checkmark$ & \\
\hline & $\mathrm{NO}_{2}$ & 0.87 & 5.6 & 4.1 & 0.6 & $\checkmark$ & \\
\hline & $\mathrm{O}_{3 \mathrm{MAX}}$ & 0.78 & 20.9 & 12.7 & 1.3 & $\checkmark$ & $\checkmark$ \\
\hline \multirow{4}{*}{ Coloane Ambient } & $\mathrm{PM}_{10}$ & 0.89 & 8.3 & 5.7 & 1.2 & $\checkmark$ & \\
\hline & $\mathrm{PM}_{25}$ & 0.86 & 5.3 & 3.6 & 1.0 & $\checkmark$ & \\
\hline & $\mathrm{NO}_{2}$ & 0.81 & 7.8 & 5.5 & -0.1 & $\checkmark$ & \\
\hline & $\mathrm{O}_{3 \operatorname{MAX}}$ & 0.79 & 24.3 & 15.3 & -3.0 & $\checkmark$ & $\checkmark$ \\
\hline
\end{tabular}


Table 4. Variables and model equations for each pollutant per air quality monitoring station in the 2013 to 2018 model.

\begin{tabular}{|c|c|c|}
\hline Station & Pollutant & Model Equations \\
\hline \multirow{3}{*}{ Macao Roadside } & $\mathrm{NO}_{2}$ & $\mathrm{NO}_{2}=0.897 \times \mathrm{NO}_{2} \_16 \mathrm{D} 1+0.011 \times \mathrm{H} 850-0.151 \times \mathrm{HRMN}$ \\
\hline & $\mathrm{PM}_{10}$ & $\mathrm{PM}_{10}=0.913 \times$ PM $10 \_16 \mathrm{D} 1+0.015 \times \mathrm{H} 850-0.208 \times \mathrm{HRMD}$ \\
\hline & $\mathrm{PM}_{2.5}$ & $\mathrm{PM}_{2.5}=0.943 \times \mathrm{PM}_{25} \_16 \mathrm{D} 1+0.006 \times \mathrm{H} 850-0.091 \times \mathrm{HRMD}$ \\
\hline \multirow{4}{*}{ Macao Residential } & $\mathrm{NO}_{2}$ & $\mathrm{NO}_{2}=0.913 \times \mathrm{NO}_{2} \_16 \mathrm{D} 1+0.007 \times \mathrm{H} 850-0.087 \times \mathrm{HRMN}$ \\
\hline & $\mathrm{PM}_{10}$ & $\mathrm{PM}_{10}=0.896 \times \mathrm{PM}_{10} \_16 \mathrm{D} 1+0.016 \times \mathrm{H} 850-0.224 \times \mathrm{HRMD}$ \\
\hline & $\mathrm{PM}_{2.5}$ & $\mathrm{PM}_{2.5}=0.926 \times \mathrm{PM}_{25} \_16 \mathrm{D} 1+0.004 \times \mathrm{H} 850-0.176 \times \mathrm{TD} \_\mathrm{MD}$ \\
\hline & $\mathrm{O}_{3 \mathrm{MAX}}$ & $\begin{array}{c}\mathrm{O}_{3 \mathrm{MAX}}=1.089 \times \mathrm{O}_{3 \_\mathrm{MAX}}+16 \mathrm{D} 1-0.344 \times \mathrm{O}_{3 \_\mathrm{MAX}} 23 \mathrm{D} 1-1.303 \times \\
\text { TD_MD }+1.437 \times \text { T_AIR_MX }\end{array}$ \\
\hline \multirow[b]{4}{*}{ Taipa Ambient } & $\mathrm{NO}_{2}$ & $\mathrm{NO}_{2}=0.914 \times \mathrm{NO}_{2} \_16 \mathrm{D} 1+0.004 \times \mathrm{H} 850+0.734 \times \mathrm{STB} 925$ \\
\hline & $\mathrm{PM}_{10}$ & $\mathrm{PM}_{10}=0.905 \times \mathrm{PM}_{10 \_} 16 \mathrm{D} 1+0.014 \times \mathrm{H} 850-0.205 \times \mathrm{HRMD}$ \\
\hline & $\mathrm{PM}_{2.5}$ & $\mathrm{PM}_{2.5}=0.928 \times \mathrm{PM}_{25} \_16 \mathrm{D} 1+0.006 \times \mathrm{H} 850-0.093 \times \mathrm{HRMD}$ \\
\hline & $\mathrm{O}_{3 \mathrm{MAX}}$ & 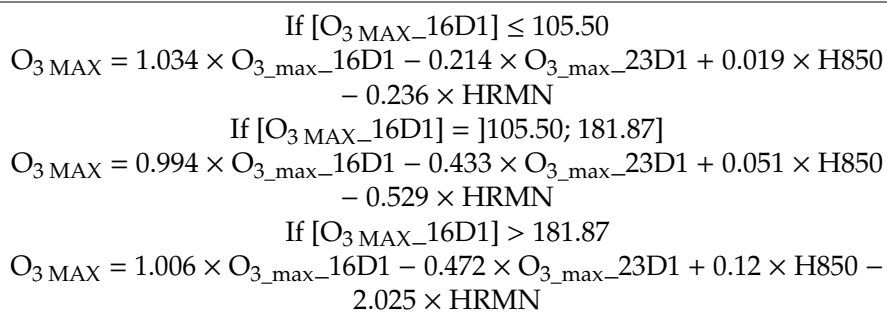 \\
\hline \multirow[b]{4}{*}{ Taipa Residential } & $\mathrm{NO}_{2}$ & $\mathrm{NO}_{2}=0.859 \times \mathrm{NO}_{2} \_16 \mathrm{D} 1+0.007 \times \mathrm{H} 850-0.271 \times \mathrm{TD} \_\mathrm{MD}$ \\
\hline & $\mathrm{PM}_{10}$ & $\mathrm{PM}_{10}=0.902 \times \mathrm{PM}_{10 \_} 16 \mathrm{D} 1+0.015 \times \mathrm{H} 850-0.204 \times \mathrm{HRMD}$ \\
\hline & $\mathrm{PM}_{2.5}$ & $\mathrm{PM}_{2.5}=0.938 \times \mathrm{PM}_{25} \_16 \mathrm{D} 1-0.607 \times \mathrm{TD} \_\mathrm{MD}+0.703 \times \mathrm{TAR} 925$ \\
\hline & $\mathrm{O}_{3 \mathrm{MAX}}$ & 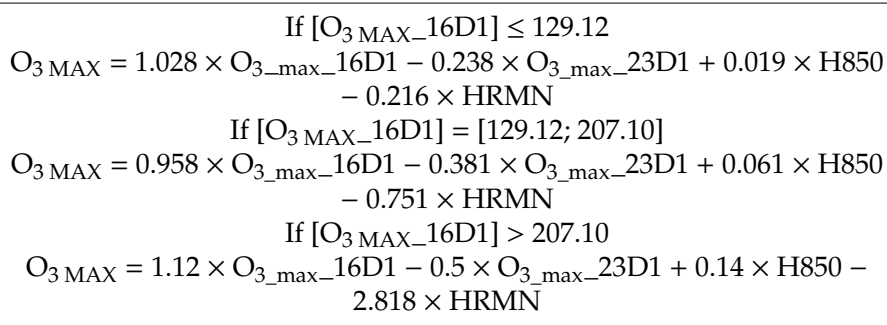 \\
\hline \multirow[b]{4}{*}{ Coloane Ambient } & $\mathrm{NO}_{2}$ & $\mathrm{NO}_{2}=0.931 \times \mathrm{NO}_{2} \_16 \mathrm{D} 1-0.503 \times \mathrm{TD} \_\mathrm{MD}+0.628 \times \mathrm{TAR} 925$ \\
\hline & $\mathrm{PM}_{10}$ & $\mathrm{PM}_{10}=0.904 \times \mathrm{PM}_{10} \_16 \mathrm{D} 1+0.015 \times \mathrm{H} 850-0.214 \times \mathrm{HRMD}$ \\
\hline & $\mathrm{PM}_{2.5}$ & $\mathrm{PM}_{2.5}=0.927 \times \mathrm{PM}_{25 \_} 16 \mathrm{D} 1+0.005 \times \mathrm{H} 850-0.069 \times \mathrm{HRMN}$ \\
\hline & $\mathrm{O}_{3 \mathrm{MAX}}$ & 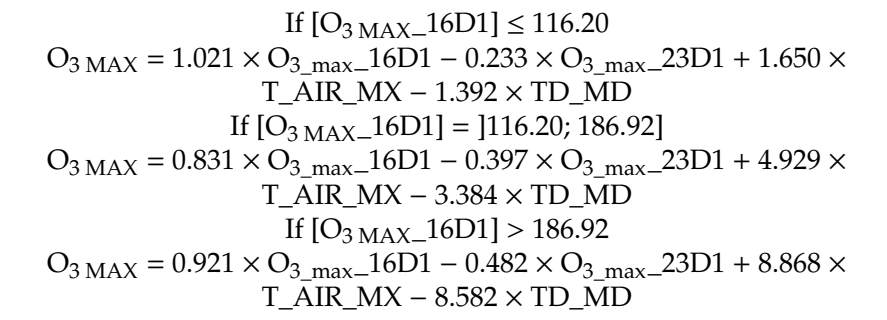 \\
\hline
\end{tabular}

\subsection{Air Quality During the High Pollution Episode}

Taipa Ambient is the representative background location for Macao, and was chosen to assess the background levels of $\mathrm{PM}_{2.5}$ and $\mathrm{O}_{3}$ during the extreme pollution episode.

The influx of tourists coming to Macao, in light of the Chinese National Holiday, contributed to an high pollution episode that occurred during late September and early October 2019, with peak daily levels of $\mathrm{PM}_{2.5}$ concentration exceeding $55 \mu \mathrm{g} / \mathrm{m}^{3}$ and $\mathrm{O}_{3} \mathrm{MAX}$ levels exceeding $400 \mu \mathrm{g} / \mathrm{m}^{3}$, largely exceeding the threshold level recommended by the WHO. 
The levels of $\mathrm{PM}_{2.5}$ and $\mathrm{O}_{3 \mathrm{MAX}}$ concentrations for Taipa Ambient during the Chinese National Holiday in 2019 (from September to November) are presented in Figures 1 and 2.

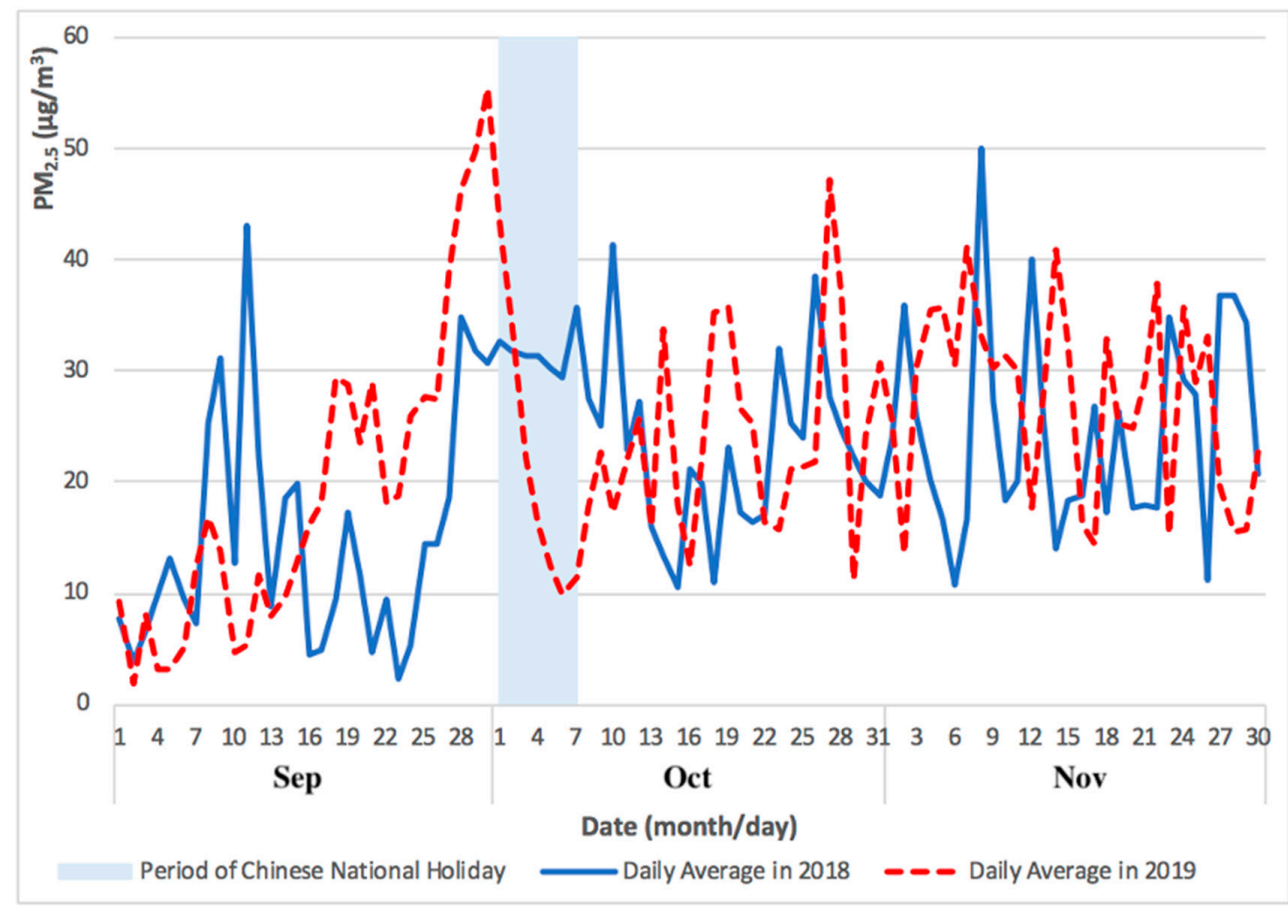

Figure 1. $\mathrm{PM}_{2.5}$ concentrations for Taipa Ambient highlighting a pollution episode immediately before, and during, the Chinese National Holiday of 2018 and 2019 (September to November).

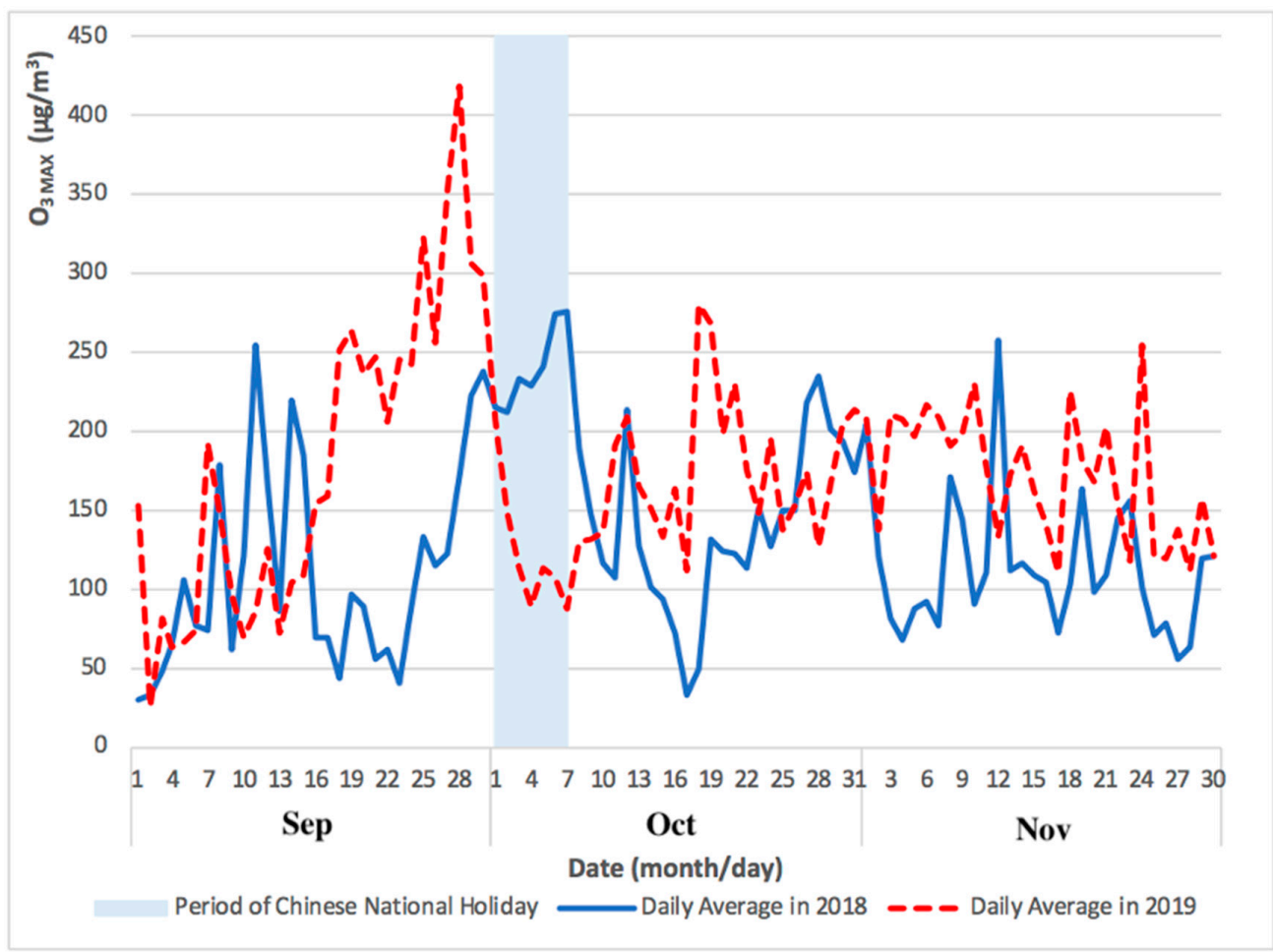

Figure 2. $\mathrm{O}_{3 \mathrm{MAX}}$ concentrations for Taipa Ambient highlighting a pollution episode immediately before, and during, the Chinese National Holiday of 2018 and 2019 (September to November). 
Figures 1 and 2 showed the comparison of daily average $\mathrm{PM}_{2.5}$ and $\mathrm{O}_{3} \mathrm{MAX}$ concentration during 2018 and 2019, from a month before in September and a month after in November of the Chinese National Holiday. The pollution episode of 2019 occurred just before and going well into the period of Chinese National Holiday (1 to 7 October).

As shown in Figures 1 and 2, the levels of $\mathrm{PM}_{2.5}$ and $\mathrm{O}_{3} \mathrm{MAX}$ concentration peaked immediately before, and during, the Chinese National Holiday in late September and early October 2019. The monthly mean concentration of $\mathrm{PM}_{2.5}$ (from September to November) during the Chinese National Holiday in 2019 was $19 \mu \mathrm{g} / \mathrm{m}^{3}, 24 \mu \mathrm{g} / \mathrm{m}^{3}$, and $28 \mu \mathrm{g} / \mathrm{m}^{3}$, respectively. In addition, the monthly mean concentration of $\mathrm{O}_{3} \mathrm{MAX}$ (from September to November) during the Chinese National Holiday in 2019 was $181 \mu \mathrm{g} / \mathrm{m}^{3}$, $163 \mu \mathrm{g} / \mathrm{m}^{3}$, and $172 \mu \mathrm{g} / \mathrm{m}^{3}$, respectively.

The levels of $\mathrm{O}_{3 \text { MAx }}$ concentrations reached its peak during the late September and early October due to meteorological factors including predominant winds from the north and east, from the Guangdong Province and Hong Kong, respectively. Temperatures were high in conjunction with low wind speed. The average daily temperature during the ozone peak episode that took place the two-weeks before the Chinese National Holiday (October $1 \mathrm{st}$ ) was $28^{\circ} \mathrm{C}$, while the maximum daily average was $31^{\circ} \mathrm{C}$. Average wind speed was $2.5 \mathrm{~m} / \mathrm{s}$.

Due to the shutdown of nearby industrial sectors during the period of Chinese National Holiday, there were lower emissions of nitrogen oxides associated with the decreased load from the coal power plants in the northern region, usually supporting the operation of the factories. Therefore, this caused a decrease $\mathrm{NO}_{\mathrm{x}}$, the precursor of $\mathrm{O}_{3}$. However, the increase in emissions of VOCs and NOx by vehicles, with chemical reactions in the presence of sunlight, may have caused the peak levels of ozone concentrations under these high temperature favorable conditions.

\subsection{Air Quality During the Low Pollution Episode}

In contrast, the COVID-19 pandemic has led to the Macao government's decision to temporarily suspend the operation of the casinos and entertainment industry and highly restrict cross border movements, as a preventive measure to reduce population mobility within the region of Macao. As a result, it has caused a low pollution episode during late January and early February 2020, with daily levels of $\mathrm{PM}_{2.5}$ concentration reaching a record low at $2 \mu \mathrm{g} / \mathrm{m}^{3}$ and $\mathrm{O}_{3} \mathrm{MAX}$ levels at $50 \mu \mathrm{g} / \mathrm{m}^{3}$. The reduction of population mobility, and consequently, of traffic emissions in Macao and its nearby Guangdong Province, lead to this lowest $\mathrm{PM}_{2.5}$ concentration levels.

As shown in Figure 3, the levels of $\mathrm{PM}_{2.5}$ concentrations remained low during the initial outbreak of COVID-19 pandemic in Macao (from January to February 2020), slowly recovering to pre-COVID-19 values in March 2020. As shown in Figure 4, the levels of $\mathrm{O}_{3}$ MAX concentration remained high during the initial outbreak of COVID-19 pandemic in Macao (from January to February 2020) and the high levels continued into March 2020. The higher levels of $\mathrm{O}_{3}$ MAx concentration were associated with lower $\mathrm{NO}_{X}$ emissions, which led to a weakened $\mathrm{O}_{3}$ titration by $\mathrm{NO}$ during the COVID-19 pandemic lockdown in the nearby Guangdong Province [4].

Despite industrial emission being a major contributor to the $\mathrm{PM}_{2.5}$ pollution in China prior to COVID-19 pandemic lockdown period, the residential emission contributed to 39\% of total $\mathrm{PM}_{2.5}$ emissions in China, so the emissions of $\mathrm{PM}_{2.5}$ during the lockdown period may have originated from residential areas [5].

The comparison of $\mathrm{PM}_{2.5}$ and $\mathrm{O}_{3}$ MAx concentrations for Taipa Ambient during the previous year of 2019 and COVID-19 pandemic in 2020 (January to March) is presented in Figures 3 and 4. 


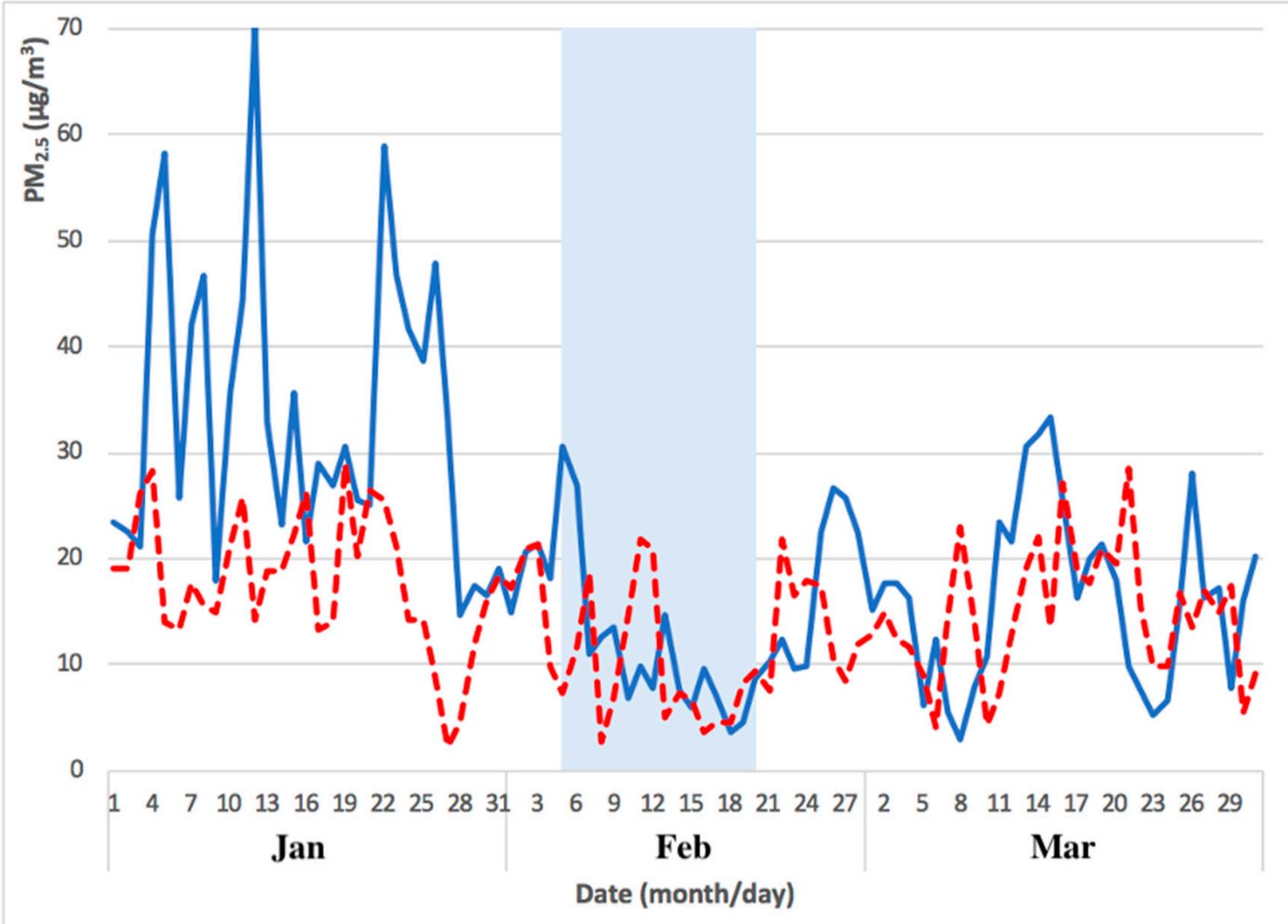

Period of COVID-19 Preventive Measure —Daily Average in 2019 _ - - Daily Average in 2020

Figure 3. Comparison of $\mathrm{PM}_{2.5}$ concentrations for Taipa Ambient during the previous year of 2019 and COVID-19 pandemic in 2020 (January to March).

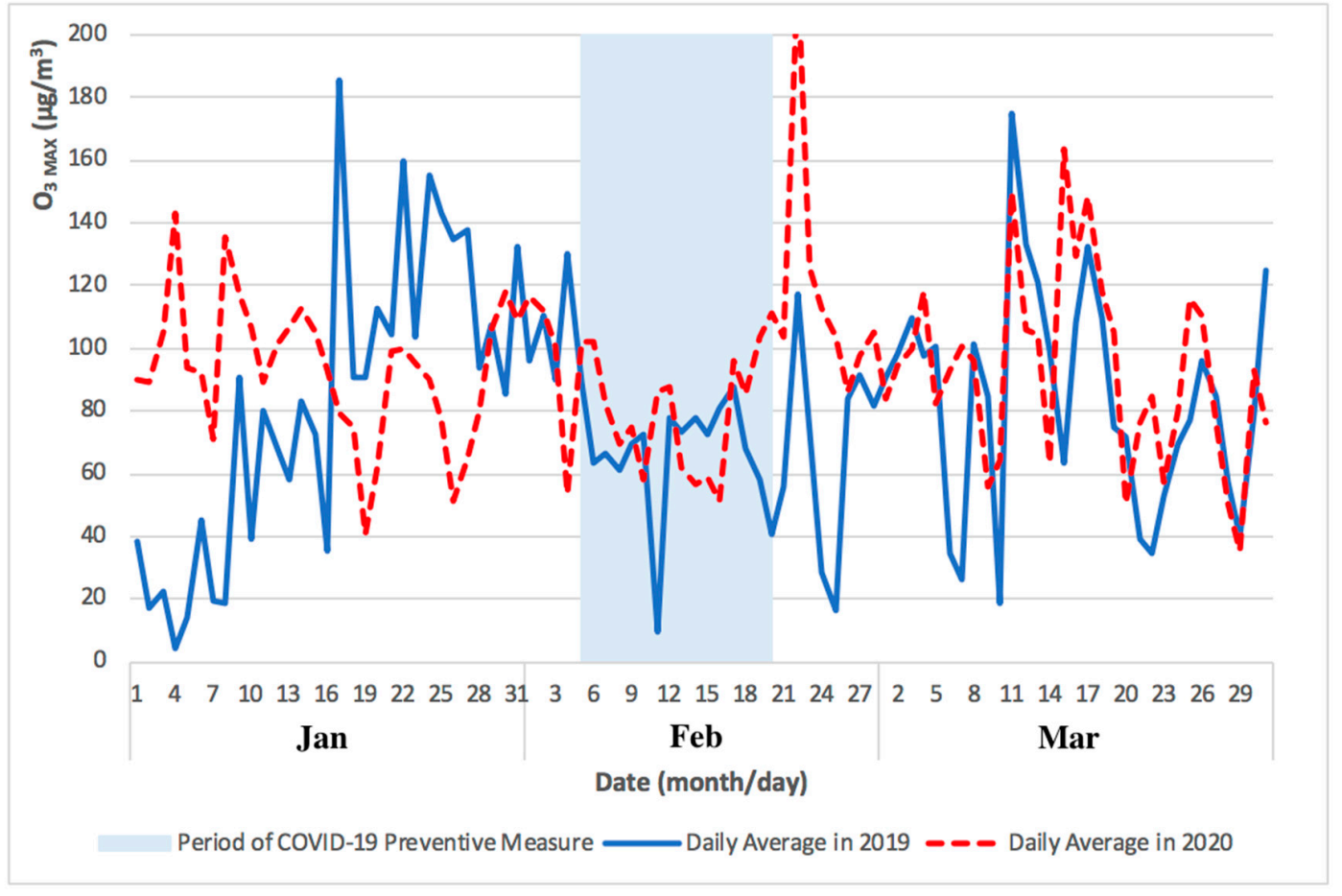

Figure 4. Comparison of $\mathrm{O}_{3} \mathrm{MAX}$ concentrations for Taipa Ambient during the previous year of 2019 and COVID-19 pandemic in 2020 (January to March). 
As shown in Figure 5, the difference between monthly mean concentration (from January to March) of $\mathrm{PM}_{2.5}$ concentration in 2019 and 2020 was $16 \mu \mathrm{g} / \mathrm{m}^{3}, 2 \mu \mathrm{g} / \mathrm{m}^{3}$, and $1 \mu \mathrm{g} / \mathrm{m}^{3}$, respectively. As shown in Figure 6, the difference between monthly mean concentration (from January to March) of $\mathrm{O}_{3} \mathrm{MAX}$ concentration in 2019 and 2020 was $12 \mu \mathrm{g} / \mathrm{m}^{3}, 21 \mu \mathrm{g} / \mathrm{m}^{3}$, and $9 \mu \mathrm{g} / \mathrm{m}^{3}$, respectively.

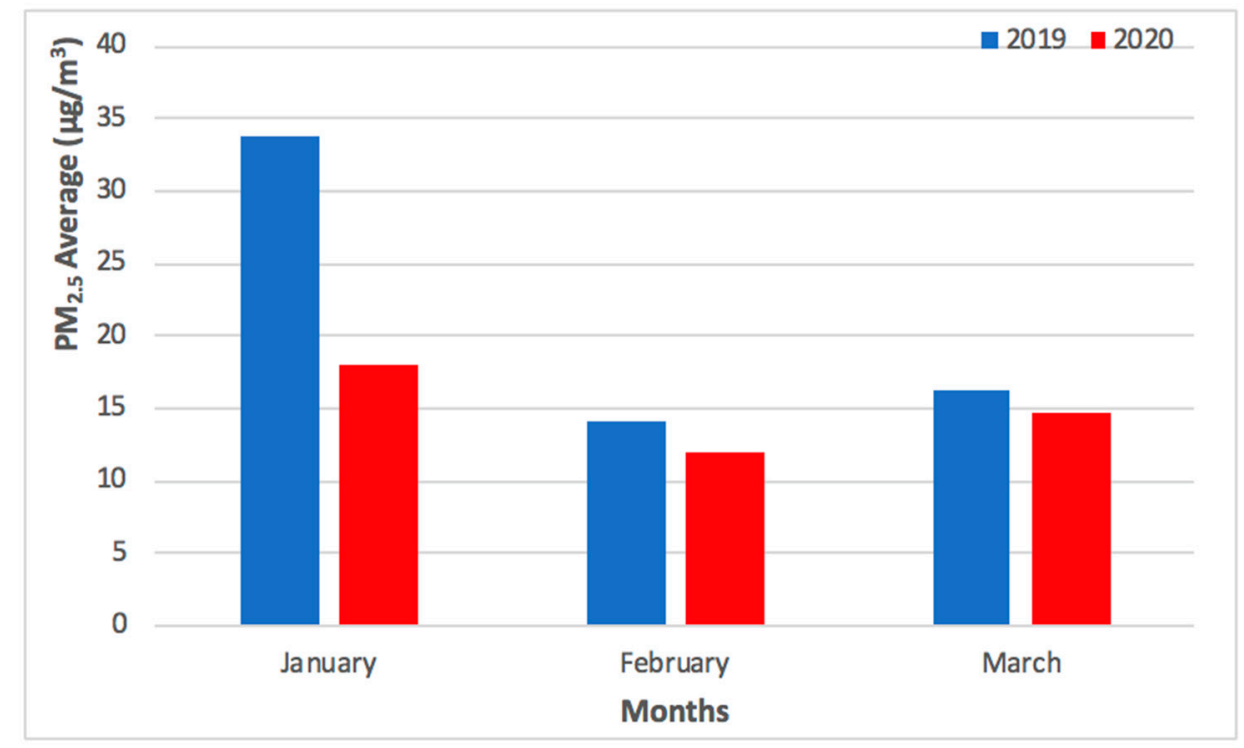

Figure 5. Monthly mean $\mathrm{PM}_{2.5}$ concentrations for Taipa Ambient during the previous year of 2019 and COVID-19 pandemic in 2020 (January to March).

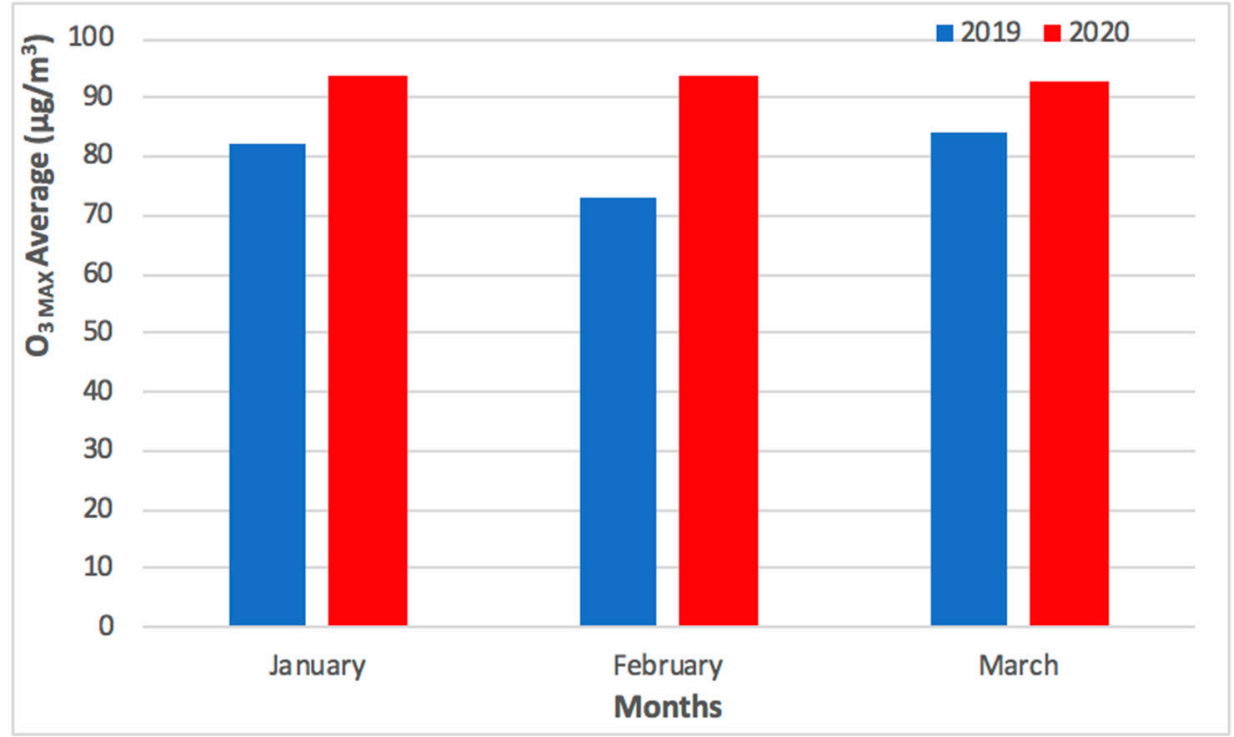

Figure 6. Monthly mean $\mathrm{O}_{3}$ MAX concentrations for Taipa Ambient during the previous year of 2019 and COVID-19 pandemic in 2020 (January to March).

The monthly mean concentration of $\mathrm{PM}_{2.5}$ and $\mathrm{O}_{3} \mathrm{MAX}$ concentration for Taipa Ambient during the previous year of 2019 and COVID-19 pandemic in 2020 (January to March) is presented in Figures 5 and 6. Overall, the preventive measures of COVID-19 pandemic may not have caused a significant difference in the levels of $\mathrm{PM}_{2.5}$ and $\mathrm{O}_{3}$ concentration in Macao, as the levels from February to March 2020 were similar to that of the previous year, 2019. 


\subsection{Air Quality Pollution Episodes Discussion}

The air quality of Macao, a territory with only $32.8 \mathrm{~km}^{2}$, is heavily influenced by external factors, in particular by human activities that occur in the much larger and neighboring Guangdong province. Our study shows the extent to which an increase in mobility associated with Chinese National Holiday, or a decrease in the same factors, associated with the COVID-19 preventive measures period, impacts air quality in Macao.

The levels of $\mathrm{PM}_{2.5}$ concentrations significantly reduced after the first confirmed case of COVID-19 pandemic in Macao on January 22nd, 2020, which caused panic and anxiety in the local population, and continued by the announcement of casino closures by the Macao government as part of the preventive measures for COVID-19 from February 5th to 20th, 2020. As some of the preventive measures, in particular, the 15 days mandatory casino closure have been lifted, the fear and tension of the local residents has eased, which has promoted population mobility. Although the levels of $\mathrm{PM}_{2.5}$ concentrations in Macao improved significantly during late January and early February 2020, the levels of $\mathrm{PM}_{2.5}$ concentrations gradually returned to normal in March 2020 after some of the preventive measures began to be lifted in Macao and its nearby Guangdong Province.

\subsection{Air Quality Pollution Episodes Forecast}

Regarding the model behavior in predicting $\mathrm{PM}_{2.5}$ and $\mathrm{O}_{3 \mathrm{MAX}}$ during the high pollution episode (Chinese National Holiday), observed and predicted $\mathrm{PM}_{2.5}$ and $\mathrm{O}_{3} \mathrm{MAX}$ concentrations are presented in Figures 7 and 8.

As shown in Figures 7 and 8, the levels of $\mathrm{PM}_{2.5}$ and $\mathrm{O}_{3} \mathrm{MAX}$ concentration peaked during late September and early October 2019. The $\mathrm{PM}_{2.5}$ predicted levels followed the primary trend of the measured concentrations and followed the concentration peak represented in Figure 7 . The model for $\mathrm{O}_{3 \mathrm{MAX}}$ also followed the primary trend, but it was more difficult to represent the concentration peak. The forecast model for $\mathrm{PM}_{2.5}$ has a higher $\mathrm{R}^{2}$ in comparison to the model of $\mathrm{O}_{3 \mathrm{MAX}}$, because the maximum hourly concentration of $\mathrm{O}_{3 \mathrm{MAX}}$ is more challenging to predict in comparison to the $24 \mathrm{~h}$ average of $\mathrm{PM}_{2.5}$, as there is influence from the regional precursors sources and also its complex chemistry with solar radiation for $\mathrm{O}_{3}$ formation, which led to a higher degree of variability.

Due to the different nature of $\mathrm{PM}_{2.5}$ and $\mathrm{O}_{3 \mathrm{MAX}}$, the forecast model performed better in the prediction of $\mathrm{PM}_{2.5}$ in comparison to $\mathrm{O}_{3}$ MAX. This can be demonstrated in the higher $\mathrm{R}^{2}$ values in the $\mathrm{PM}_{2.5}$ forecast model. The observed and predicted $\mathrm{PM}_{2.5}$ and $\mathrm{O}_{3 \mathrm{MAX}}$ concentrations, during the low pollution episode (implementation of COVID-19 preventive measures), are presented in Figures 9 and 10.

The 2013 to 2018 model successfully predicted both the high and low pollution episodes, for $\mathrm{PM}_{2.5}$

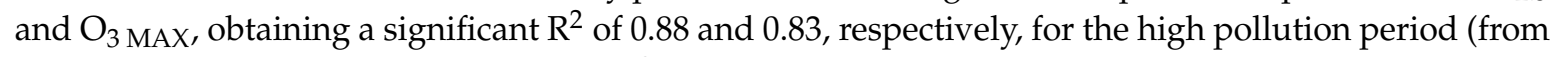
September to November 2019), and an $R^{2}$ of 0.82 and 0.75 , respectively, for the low pollution period (from January to March 2020). The $\mathrm{R}^{2}$ obtained for the entire year of 2019 was 0.86 for both $\mathrm{PM}_{2.5}$ and $\mathrm{O}_{3 \text { MAX }}$. The statistical forecast model has been shown to be capable to predict, with a high coefficient of determination, the next $24 \mathrm{~h}$. 

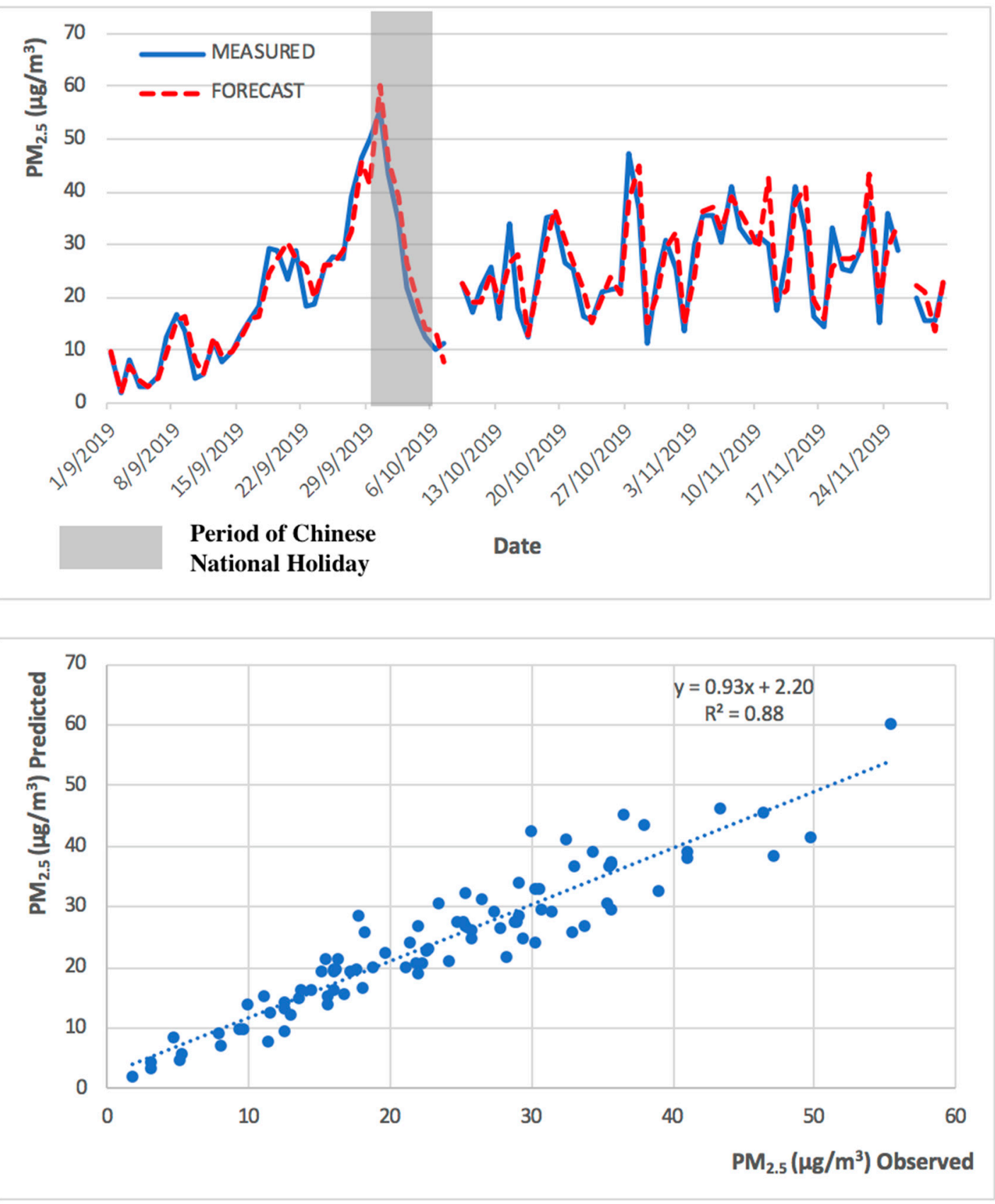

Figure 7. Observed and predicted $\mathrm{PM}_{2.5}$ concentrations for Taipa Ambient during Chinese National Holiday (from September to November 2019). 

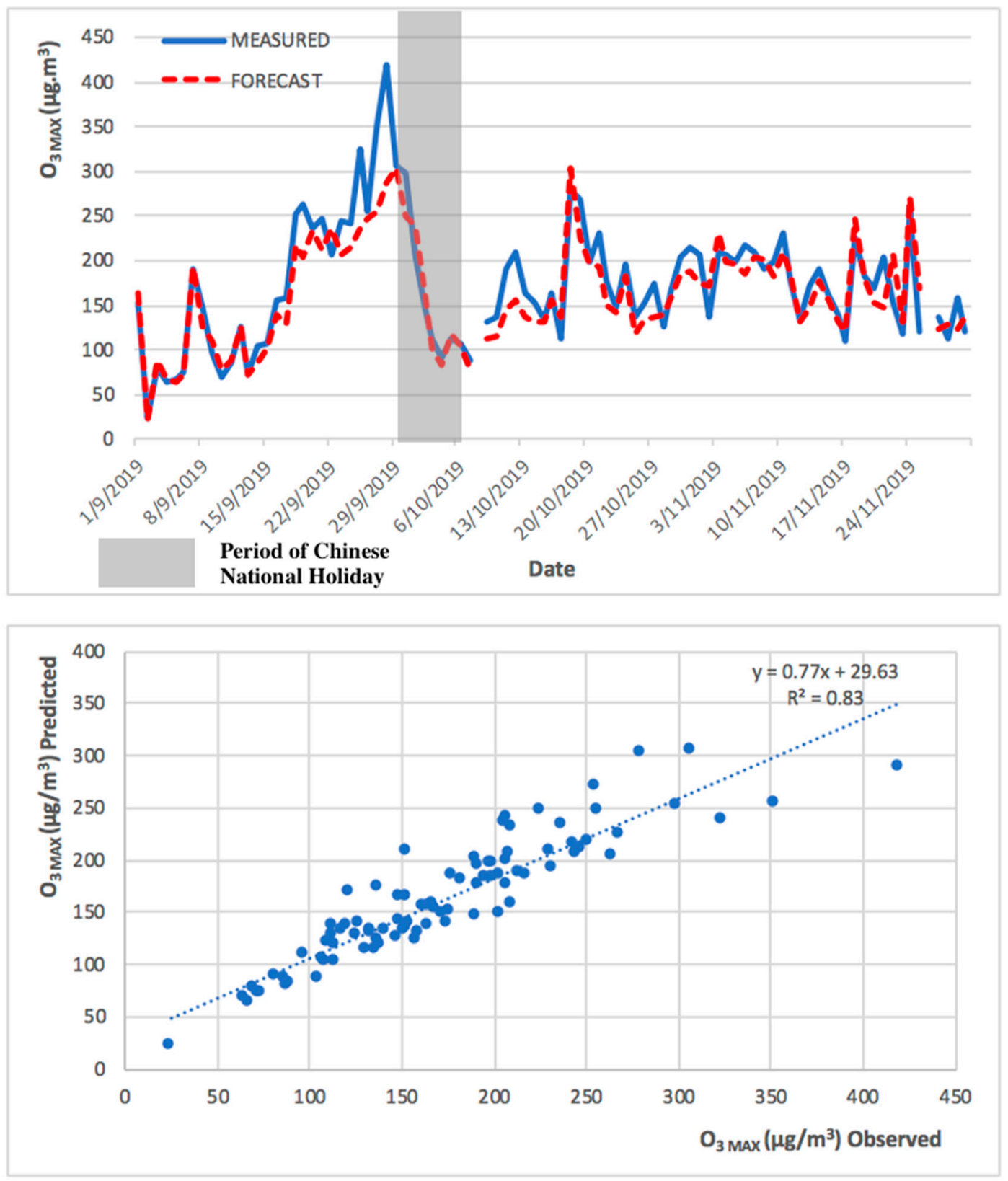

Figure 8. Observed and predicted $\mathrm{O}_{3}$ MAX concentrations for Taipa Ambient during Chinese National Holiday (from September to November 2019). 

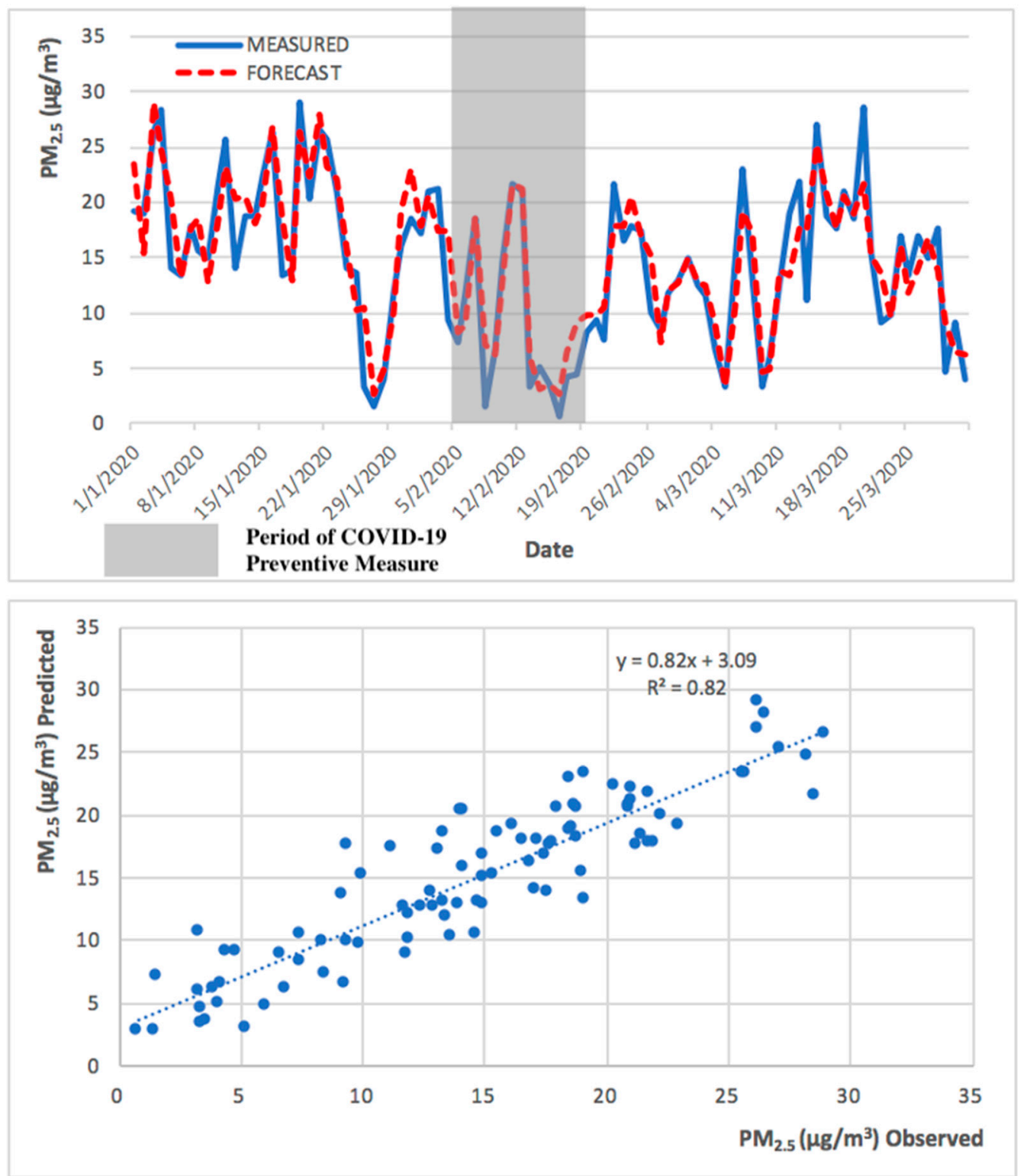

Figure 9. Observed and predicted $\mathrm{PM}_{2.5}$ concentrations for Taipa Ambient during preventive measures of COVID-19 pandemic (from January to March 2020). 

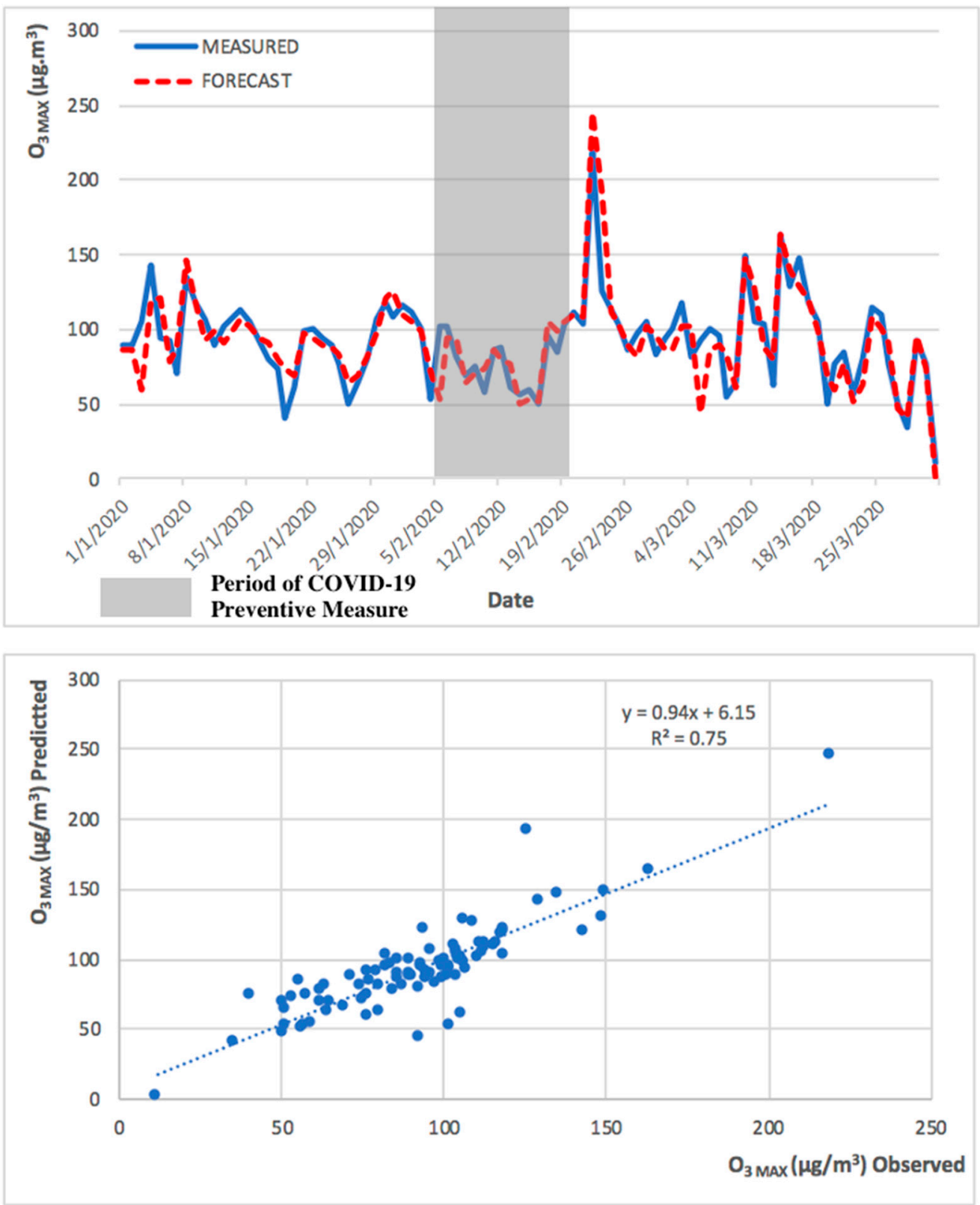

Figure 10. Observed and predicted $\mathrm{O}_{3} \mathrm{MAX}$ concentrations for Taipa Ambient during preventive measures of COVID-19 pandemic (from January to March 2020).

\section{Conclusions}

As expected, the 2013 to 2018 model performed best with the highest $\mathrm{R}^{2}$ and lowest RMSE, MAE, and BIAS as compared with the 2013 to 2016 model and the 2015 to 2018 model. The additional two years of data helped to improve the accuracy and stability of the forecast of the 2013-2018 model.

The 2013-2018 model was able to successfully predict the high pollution episode during the Chinese National Holiday in late September and early October 2019 and the low pollution episode during the preventive measures period of COVID-19 pandemic in late January and early February 2020. This shows that this model can be reliably applied to forecast next-day pollutants concentrations across different magnitude levels of air pollution, being a useful tool for mitigation of air pollution impacts.

In addition, this shows that an improvement of global air quality in the territory is possible but it is tightly linked to the implementation of air pollution control measures in the industry and mobility sectors in Macao, in particular, in Guangdong Province. As previously studied, the air pollution 
problem associated with $\mathrm{PM}_{2.5}$ and $\mathrm{O}_{3 \mathrm{MAX}}$ is a regional problem that is not only limited to Macao, but also in the nearby regions of Hong Kong and Guangdong Province.

Author Contributions: Data curation, M.T.L., J.M., and L.M.; funding acquisition, D.G. and F.F.; methodology, M.T.L.; software, L.M.; supervision, D.G. and F.F.; validation, M.T.L., J.M., and L.M.; writing-original draft, M.T.L.; and writing-review and editing, M.T.L., J.M., D.G., and F.F. All authors have read and agreed to the published version of the manuscript.

Funding: This research was funded by [Fundação para a Ciência e Tecnologia, I.P., Portugal] grant number [UID/AMB/04085/2019] and the APC was funded by [CENSE].

Acknowledgments: The work developed was supported by The Macao Meteorological and Geophysical Bureau (SMG).

Conflicts of Interest: The authors declare no conflict of interest.

\section{References}

1. Pope, C.A.; Dockery, D.W. Health effects of fine particulate air pollution: Lines that connect. J. Air Waste Manag. Assoc. 2006, 56, 709-742. [CrossRef] [PubMed]

2. Ghazali, N.A.; Ramli, N.A.; Yahaya, A.S.; Yusof, N.F.F.M.; Sansuddin, N.; Al Madhoun, W.A. Transformation of nitrogen dioxide into ozone and prediction of ozone concentrations using multiple linear regression techniques. Environ. Monit. Assess. 2009, 165, 475-489. [CrossRef] [PubMed]

3. Abdullah, A.; Ismail, M.; Yuen, F.S.; Abdullah, S.; Elhadi, R. The relationship between daily maximum temperature and daily maximum ground level ozone concentration. Pol. J. Environ. Stud. 2017, 26, 517-523. [CrossRef]

4. Li, L.; Li, Q.; Huang, L.; Wang, Q.; Zhu, A.; Xu, J.; Liu, Z.; Li, H.; Shi, L.; Li, R.; et al. Air quality changes during the COVID-19 lockdown over the Yangtze River Delta Region: An insight into the impact of human activity pattern changes on air pollution variation. Sci. Total Environ. 2020, 732. [CrossRef]

5. Wang, Y.; Yuan, Y.; Wang, Q.; Liu, C.G.; Zhi, Q.; Cao, J. Changes in air quality related to the control of coronavirus in China: Implications for traffic and industrial emissions. Sci. Total Environ. 2020, 731, 139133. [CrossRef] [PubMed]

6. Wendt, E.A.; Quinn, C.W.; Miller-Lionberg, D.D.; Tryner, J.; Christian L'orange; Ford, B.; Yalin, A.P.; Pierce, J.R.; Jathar, S.H.; Volckens, J.; et al. A low-cost monitor for simultaneous measurement of fine particulate matter and aerosol optical depth-part 1: Specifications and testing. Atmos. Meas. Tech. 2019, 12, 5431-5441. [CrossRef]

7. Brauer, M.; Freedman, G.; Frostad, J.; Van Donkelaar, A.; Martin, R.V.; Dentener, F.; Van Dingenen, R.; Estep, K.; Amini, H.; Apte, J.; et al. Ambient air pollution exposure estimation for the global burden of disease 2013. Environ. Sci. Technol. 2015, 50, 79-88. [CrossRef]

8. Forouzanfar, M.H.; Afshin, A.; Alexander, L.T.; Anderson, H.R.; Bhutta, A.Z.; Biryukov, S.; Brauer, M.; Burnett, R.; Cercy, K.; Charlson, F.J.; et al. Global, regional, and national comparative risk assessment of 79 behavioural, environmental and occupational, and metabolic risks or clusters of risks, 1990-2015: A systematic analysis for the Global Burden of Disease Study 2015. Lancet 2016, 388, 1659-1724. [CrossRef]

9. EEA. Air quality in Europe-2019 report-EEA Report No 10/2019; European Environment Agency: Copenhagen, Denmark, 2019; ISBN 978-92-9480-088-6.

10. RCP. Report of a working party February 2016; Royal College of Physicians: London, UK, 2016; ISBN 9781860165672.

11. Song, J.; Liu, Y.; Lu, M.; An, Z.; Lu, J.; Chao, L.; Zheng, L.; Li, J.; Yao, S.; Wu, W.; et al. Short-term exposure to nitrogen dioxide pollution and the risk of eye and adnexa diseases in Xinxiang, China. Atmos. Environ. 2019, 218,117001 . [CrossRef]

12. Jevtic, M.; Dragić, N.; Bijelović, S.; Popović, M. Cardiovascular diseases and air pollution in Novi Sad, Serbia. Int. J. Occup. Med. Environ. Health 2014, 27, 153-164. [CrossRef]

13. Qi, J.; Ruan, Z.; Qian, Z.M.; Yin, P.; Yang, Y.; Acharya, B.K.; Wang, L.; Lin, H. Potential gains in life expectancy by attaining daily ambient fine particulate matter pollution standards in mainland China: A modeling study based on nationwide data. PLoS Med. 2020, 17, e1003027. [CrossRef] [PubMed] 
14. Chen, W.; Li, A.; Zhang, F. Roadside atmospheric pollution: Still a serious environmental problem in Beijing, China. Air Qual. Atmos. Health 2018, 11, 1203-1216. [CrossRef]

15. Ai, Z.; Mak, C.M.; Lee, H. Roadside air quality and implications for control measures: A case study of Hong Kong. Atmos. Environ. 2016, 137, 6-16. [CrossRef]

16. Zheng, Y.; Che, H.; Zhao, T.; Zhao, H.; Gui, K.; Sun, T.; An, L.; Yu, J.; Liu, C.; Jiang, Y.; et al. Aerosol optical properties observation and its relationship to meteorological conditions and emission during the Chinese National Day and Spring Festival holiday in Beijing. Atmos. Res. 2017, 197, 188-200. [CrossRef]

17. Fu, S.; Gu, Y. Highway toll and air pollution: Evidence from Chinese cities. J. Environ. Econ. Manag. 2017, 83, 32-49. [CrossRef]

18. Ralph, R.; Lew, J.; Zeng, T.; Francis, M.; Xue, B.; Roux, M.; Ostadgavahi, A.T.; Rubino, S.; Dawe, N.J.; Al-Ahdal, M.N.; et al. 2019-nCoV (Wuhan virus), a novel Coronavirus: Human-to-human transmission, travel-related cases, and vaccine readiness. J. Infect. Dev. Ctries. 2020, 14, 3-17. [CrossRef]

19. Wang, P.; Chen, K.; Zhu, S.; Wang, P.; Zhang, H. Severe air pollution events not avoided by reduced anthropogenic activities during COVID-19 outbreak. Resour. Conserv. Recycl. 2020, 158, 104814. [CrossRef]

20. Shi, X.; Brasseur, G.P. The Response in Air Quality to the Reduction of Chinese Economic Activities During the COVID-19 Outbreak. Geophys. Res. Lett. 2020, 47, 1-8. [CrossRef]

21. Bao, R.; Zhang, A. Does lockdown reduce air pollution? Evidence from 44 cities in northern China. Sci. Total Environ. 2020, 731, 139052. [CrossRef]

22. Ma, J.; Cheng, J.C.; Lin, C.; Tan, Y.; Zhang, J. Improving air quality prediction accuracy at larger temporal resolutions using deep learning and transfer learning techniques. Atmos. Environ. 2019, 214, 116885. [CrossRef]

23. Masih, A. Machine learning algorithms in air quality modeling. J. Environ Sci. Manag. 2019, 5, 515-534. [CrossRef]

24. Lin, H.; Jin, J.; Herik, J.V.D. Air quality forecast through integrated data assimilation and machine learning. In Proceedings of the 11th International Conference on Agents and Artificial Intelligence, Prague, Czech Republic, 19-21 February 2019; Volume 2, pp. 787-793. [CrossRef]

25. Pagowski, M.; Grell, G.; Devenyi, D.; Peckham, S.; McKeen, S.; Gong, W.; Monache, L.D.; McHenry, J.; McQueen, J.; Lee, P. Application of dynamic linear regression to improve the skill of ensemble-based deterministic ozone forecasts. Atmos. Environ. 2006, 40, 3240-3250. [CrossRef]

26. Lei, M.T.; Monjardino, J.; Mendes, L.; Gonçalves, D.; Ferreira, F. Macao air quality forecast using statistical methods. Air Qual. Atmos. Health 2019, 12, 1049-1057. [CrossRef]

27. Kocijan, J.; Gradišar, D.; Stepančič, M.; Božnar, M.Z.; Grašič, B.; Mlakar, P. Selection of the data time interval for the prediction of maximum ozone concentrations. Stoch. Environ. Res. Risk Assess. 2017, 32, 1759-1770. [CrossRef]

28. Zhang, Y.; Bocquet, M.; Mallet, V.; Seigneur, C.; Baklanov, A. Real-time air quality forecasting, part I: History, techniques, and current status. Atmos. Environ. 2012, 60, 632-655. [CrossRef]

29. Zhang, Y.; Bocquet, M.; Mallet, V.; Seigneur, C.; Baklanov, A. Real-time air quality forecasting, part II: State of the science, current research needs, and future prospects. Atmos. Environ. 2012, 60, 656-676. [CrossRef]

30. Lopes, D.; Hoi, K.I.; Mok, K.M.; Miranda, A.I.; Yuen, K.V.; Borrego, C. Air quality in the main cities of the pearl river delta region. Glob. Nest J. 2016, 18, 794-802.

31. Chen, J.; Wang, J. Prediction of PM2.5 concentration based on multiple linear regression. In Proceedings of the 2019 International Conference on Smart Grid and Electrical Automation (ICSGEA), Xiangtan, China, 10-11 August 2019; pp. 457-460. [CrossRef]

32. Sahanavin, N.; Prueksasit, T.; Tantrakarnapa, K. Relationship between PM 10 and PM 2.5 levels in high-traffic area determined using path analysis and linear regression. J. Environ. Sci. 2018, 69, 105-114. [CrossRef]

33. Zhao, R.; Gu, X.; Xue, B.; Zhang, J.; Ren, W. Short period PM2.5 prediction based on multivariate linear regression model. PLoS ONE 2018, 13, e0201011. [CrossRef]

34. Samadianfard, S.; Delirhasannia, R.; Kişi, Ö.; Agirre-Basurko, E. Comparative analysis of ozone level prediction models using gene expression programming and multiple linear regression. Geofizika 2013, 30, 43-74. 
35. Ahmad, M.; Alam, K.; Tariq, S.; Anwar, S.; Nasir, J.; Mansha, M. Estimating fine particulate concentration using a combined approach of linear regression and artificial neural network. Atmos. Environ. 2019, 219, 117050. [CrossRef]

36. Neto, J.; Torres, P.M.; Ferreira, F.; Boavida, F. Lisbon air quality forecast using statistical methods. Int. J. Environ. Pollut. 2009, 39, 333. [CrossRef] 